\title{
Use of random DNA amplification to generate specific molecular probes for hybridization tests and PCR-based diagnosis of Yersinia ruckeri
}

\author{
F. Argenton ${ }^{1,2}$, S. De Mas $^{2}$, C. Malocco ${ }^{1,2}$, L. Dalla Valle ${ }^{1}$, G. Giorgetti ${ }^{2}$, L. Colombo ${ }^{1, *}$ \\ ${ }^{1}$ Università di Padova, Dipartimento di Biologia, Via Trieste 75, I-35121 Padova, Italy \\ ${ }^{2}$ Istituto Zooprofilattico delle Venezie, Via G. Orus 5, I-35121 Padova, Italy
}

\begin{abstract}
We have developed a fast and convenient detection method for the etiological agent of enteric redmouth disease in rainbow trout, the bacterium Yersinia ruckeri, using the random amplification of polymorphic DNA (RAPD) technique to design specific primers for a polymerase chain reaction (PCR)-based diagnosis. In the RAPD genomic fingerprint of $Y$. ruckeri, a specific band was observed which gave no cross-hybridization with the genomes of other bacteria in Southern blot analysis. This band was cloned, sequenced, and found to bear no homology with known DNA sequences. Two primers were then synthesized to amplify by PCR the fragment lying between the terminal RAPD primer sequences of the band. The PCR assay detected specifically 3 serotypes of $Y$. ruckeri (serotypes O1, O2, and unknown) in samples with whole bacteria. It also detected the bacterium in kidney tissue from infected trout after brief digestion with proteinase K. Sample preparation was kept simple to minimize the risk of false positives due to inter-sample contamination. Because of its speed, inherent sensitivity, and apparent specificity we concluded that this diagnostic system was preferable to conventional bacteriological diagnostic tests
\end{abstract}

KEY WORDS: Bacteria - Yersinia ruckeri Disease - Enteric redmouth - Diagnosis - RAPD - PCR

\section{INTRODUCTION}

In aquaculture, bacterial infections are mostly diagnosed using classical microbiological methods involving culturing the pathogen and identifying it using biochemical and/or serological tests. These techniques are time-consuming, and, depending on the pathogen, may take days or many weeks to complete. More recently, serological techniques have been developed to speed up diagnoses by circumventing the need to culture fish pathogens. Unfortunately, however, the reliability of serological techniques can sometimes be handicapped by a lack of specificity of the antisera used in the tests. Fish health workers have recently, therefore, been turning to molecular biology in an attempt to solve their diagnostic problems.

\footnotetext{
- Addressee for correspondence.

E-mail: colombo@cribi1.bio.unipd.it
}

The polymerase chain reaction (PCR) has aided in the development of specific probes from known DNA sequences of the investigated microorganisms for fast and sensitive diagnosis of bacterial infections in aquatic species (Gustafson et al. 1992, KellnerCousin et al. 1993, Brown et al. 1994). A subsequent modification in the basic PCR protocol, which consists of the use of only 1 random primer and low annealing temperature to obtain genomic fingerprints (Welsh \& McClelland 1990, Williams et al. 1990), has dramatically increased the diagnostic power of PCR in microbiology. It has allowed detailed genotype screening without any previous knowledge of specific DNA sequence data. This kind of PCR, now referred to as RAPD (Random Amplification of Polymorphic DNA), is now being widely employed in molecular ecology, population genetics, and microbiology, because it generates molecular genetic markers at the level of genus, species or even strain. 
Thus, RAPD has already been used to characterize populations and strains of animals, plants, fungi, and bacteria (Hadrys et al. 1992, Aznar et al. 1993, Fani et al. 1993, Lawrence et al. 1993, Scieux et al. 1993). Lately, the use of individual RAPD bands to prepare specific probes in hybridization reactions has also been proposed (Hadrys et al. 1992, Fani et al. 1993).

In this paper, we have applied this kind of approach to detect the presence of Yersinia ruckeri in tissues of infected rainbow trout Oncorhynchus mykiss and to distinguish it from other pathogenic and environmental organisms. This bacterium is the etiological agent of yersiniosis or enteric redmouth disease (ERM), a serious disease in the trout farming industry (Austin \& Austin 1987). This disease was first diagnosed as a systemic infection among farmed rainbow trout in the Hagerman Valley (Idaho, USA) in 1958 and the causative agent has since been reported as occurring in North and South America, Europe, Australia, and, recently, South Africa (Bragg 1991). The causative agent is a Gram-negative, non-spore-forming, rodshaped and peritrichously flagellated bacterium (Post 1987). According to sequence analysis of the $16 \mathrm{~S}$ rRNA gene, Yersinia ruckeri forms a separate subline within the Yersiniae 5-subline cluster (Enterobacteriaceae, Proteobacteria) (Ibrahim et al. 1993). Isolates are rather uniform morphologically, biochemically, and genetically. Nevertheless, 2 biotypes, 5 O-serotypes, and 5 outer membrane protein-types (OMP-types), differing in their virulence, have been characterized in epizootiological studies (Davies 1991a, b). Moreover, strains differ slightly in estimated genome size (4.5-4.8 Mb) (Romalde et al. 1991) and greatly in extrachromosomal DNA, since serotype O1 harbours a $78 \mathrm{~kb}$ plasmid which is absent in the other serotypes or is replaced by smaller plasmids ( $<16 \mathrm{~kb}$ ) (Romalde et al. 1993).

We selected and sequenced a band from Yersinia ruckeri's RAPD profiles, which, used as a labelled probe, proved specific for $Y$. ruckeri in molecular hybridization experiments. Moreover, synthetic oligonucleotides, based on the sequence of this fragment, made possible a fast and specific PCR-based methods for detecting $Y$. ruckeri infections.

The speed of the detection system is important considering that the disease often develops into acute forms with high morbidity (up to 100\%) and high mortality (up to $50 \%$ ), especially in young, overweight or stressed fish (Post 1987). Test sensitivity is also a significant factor because ERM can be transmitted by fish with subclinical infections and because fish with such infections should not be moved to non-infected geographical areas (Austin \& Austin 1987).

\section{MATERIALS AND METHODS}

Bacterial growth and DNA extraction. Serotypes O1, O2, and unknown (here named $X$; code 87/09/115, Norway, from Apothekernes Laboratorium A.S., Oslo, Norway) of Yersinia ruckeri, Aeromonas salmonicida, Aeromonas hydrophila, Vibrio anguillarum, Proteus vulgaris, and Escherichia coli were grown according to standard methods (Austin \& Austin 1987, Quin et al. 1994). Bacterial cultures were diluted to $1.5 \mathrm{OD}_{600}$ and utilized for either direct amplification according to Mazurier \& Wernars (1992) or DNA extraction using the following procedure ( $R$. Powell pers. comm.): $1 \mathrm{ml}$ of culture was centrifuged at $10^{4} \mathrm{rpm}$ in a microfuge and the bacterial pellet resuspended in $200 \mu \mathrm{l}$ of TE buffer $(10 \mathrm{mM}$ Tris- $-1 \mathrm{Cl}, 1 \mathrm{mM}$ EDTA, $\mathrm{pH} 8.0)$ contuining $10 \mu \mathrm{gl}^{-1}$ of RNase and incubated for $10 \mathrm{~min}$ on ice. An equal volume of lysis solution $(0.15 \mathrm{M} \mathrm{NaCl}$, $0.1 \mathrm{M}$ EDTA, $15 \mathrm{mg} \mathrm{m}^{-1}$ lysozyme, $\mathrm{pH}$ 8.0) was then added, followed by incubation at $37^{\circ} \mathrm{C}$ for $2 \mathrm{~h}$. After addition of $200 \mu \mathrm{l}$ of a solution containing $0.1 \mathrm{M} \mathrm{NaCl}$, $0.5 \mathrm{M}$ Tris- $\mathrm{HCl}$, and $10 \%$ sodium dodecyl sulfate, $\mathrm{pH}$ 8.0, the mixture was frozen and thawed 3 times. After the lysis cycles, an equal volume of $0.1 \mathrm{M}$ Trissaturated $(\mathrm{pH} \mathrm{8.0)}$ phenol was added, stirred, and centrifuged at $8000 \mathrm{rpm}$ for $10 \mathrm{~min}$ in a microfuge. The aqueous phase was transferred into a sterile tube, extracted with $1 \mathrm{vol}$ of phenol/chloroform/isoamyl alcohol $(25: 24: 1)$, further extracted with 1 vol of chloroform/isoamyl alcohol (24:1), and the DNA precipitated at $-70^{\circ} \mathrm{C}$ for 1 to $4 \mathrm{~h}$ following addition of $1 \mathrm{ml}$ of icecold isopropanol. The dried pellet was resuspended in $100 \mu \mathrm{l}$ of TE buffer and the presence of DNA verified by agarose gel electrophoresis. The DNA was quantified spectrophotometrically.

Trout tissue sample preparation. Trout samples were processed as follows: blood was collected in an equal volume of a solution containing $0.1 \mathrm{M} \mathrm{NaCl}$ and $50 \mathrm{mM}$ EDTA, pH 7.8, and heated at $95^{\circ} \mathrm{C}$ for $15 \mathrm{~min}$. Small aliquots of homogenized kidney, liver, and spleen (1 to $5 \mu l)$ were collected in a solution containing $10 \mathrm{mM}$ Tris-HCl, $1 \mathrm{mM}$ EDTA, $1 \%$ Nonidet P-40, and $100 \mu \mathrm{g} \mathrm{ml}^{-1}$ Proteinase $\mathrm{K}, \mathrm{pH} 7.5$; they were then incubated at $50^{\circ} \mathrm{C}$ for $5 \mathrm{~min}$, boiled for $10 \mathrm{~min}$ and centrifuged.

Primers. The 2 synthetic oligonucleotides used as primers in RAPD reactions were: the 24-mer P1 $15^{\prime}$ CCCATGGAAAACCAACGGCTCTTC-3') and the 23mer P2 (5'-CCGGATCCCACGTCTACAGAGTG-3'), in which restriction sites for $\mathrm{NCOI}$ and BamHI, respectively, were introduced to facilitate cloning or screening for positive recombinants. The 2 primers used in PCR-based diagnosis of Yersinia ruckeri were the oligonucleotides YER1 (5'-ACGAATCAGGCTGTTACCG$\left.3^{\prime}\right)$ and YER2 (5'-TGCCTGTGCCAATGTTGGC-3'), 
obtained as indicated below. All synthetic oligonucleotides were prepared by phosphoramidite chemistry, deprotected with $30 \% \mathrm{NH}_{4} \mathrm{OH}$ at $55^{\circ} \mathrm{C}$ overnight, precipitated with 10 vol of n-butanol, washed with $70 \%$ ethanol, and dissolved in TE buffer (Sawadogo \& VanDyke 1991)

RAPD. In order to obtain a RAPD pattern specific for Yersinia ruckeri DNA, we initially tested 11 primers and different PCR temperature cycles. All amplifications were checked for reliability and the presence of amplification products in high copy number In the RAPD reaction with $\mathrm{P} 1$ and $\mathrm{P} 2$ primers, $2 \mu \mathrm{l}$ of whole bacteria or $100 \mathrm{ng}$ of purified bacterial DNA were used in a medium containing $10 \mathrm{mM}$ Tris- $\mathrm{HCl}, \mathrm{pH} 8.3$, $50 \mathrm{mM} \mathrm{KCl}, 1.5 \mathrm{mM} \mathrm{MgCl}, 0.1 \%$ Triton X-100, $100 \mu \mathrm{M}$ of each dNTP, 0.75 units (U) of Taq DNA polymerase, and $2.6 \mu \mathrm{M}$ of primer, either P1 or P2. The temperature protocol, performed in a Hybaid thermal cycler, started with denaturation $190^{\circ} \mathrm{C}$ for $1 \mathrm{~min}$ and $95^{\circ} \mathrm{C}$ for 90 s) followed by 45 thermal cycles: $95^{\circ} \mathrm{C}$ for $30 \mathrm{~s}, 48^{\circ} \mathrm{C}$ for $1 \mathrm{~min}$, and $75^{\circ} \mathrm{C}$ for $2 \mathrm{~min}$. The reaction mixture was then incubated at $75^{\circ} \mathrm{C}$ for $10 \mathrm{~min}$ and $60^{\circ} \mathrm{C}$ for $10 \mathrm{~min}$ (Fani et al. 1993). Products of amplification reactions were analysed on $1.5 \%$ agarose gels according to standard methods (Sambrook et al. 1989). One band, named Band $A$, was selected in the $\mathrm{P} 1$ primed RAPD electrophoretic profile of Y. ruckeri as a hybridization probe after agarose gel purification and digoxigenin labelling. The same band was also sequenced in order to derive the primers YER1 and YER2.

Cloning and sequencing of Band A. To design PCR primers specific for Yersinia ruckeri DNA on the basis of a known and easily amplifiable sequence, we cloned Band $A$ in a vector and sequenced it. To this end, Band A was excised from the RAPD gel, treated with both Klenow fragment and T4-polynucleotide kinase in order to prepare phosphorylated blunt ends and ligated in the SmaI site of the cloning vector pGem3. Positive colonies were analysed by restriction analysis with the enzyme $N_{c o l}$ and sequenced with either the DyeDeoxy terminator cycle sequencing kit in an $\mathrm{ABI}$ $373 \mathrm{~A}$ automatic sequencing machine, or with the Sequenase 2 kit and $\left[\alpha^{35}\right.$ S]dATP.

Southern blotting and hybridization. To determine whether DNA homologous to Band A occurred in other common bacteria, we performed Southern blot analysis on different bacterial DNA $(1 \mu g)$ digested with the restriction enzyme Ncol. The fragments, separated by $1 \%$ agarose electrophoresis, were transferred onto a nitrocellulose membrane, as described in Sambrook et al. (1989), and hybridized with the digoxigenin-labelled Band $\mathrm{A}$ as a probe, according to the manufacturer's instructions (Boehringer Mannheim)
PCR. Primers YER1 and YER2 were prepared starting from the P1 sequences at both ends of Band $A$ inwards, in order to amplify the corresponding fragment, named Band A'. The PCR with these 2 primers was performed in a $25 \mu \mathrm{l}$ volume containing either 1 to $5 \mu \mathrm{l}$ of tissue extract or $100 \mathrm{ng}$ of purified bacterial DNA. When whole bacteria were used, 1 to $2 \mu$ of suspension diluted to $1.5 \mathrm{OD}_{600}$ was used to provide the DNA template. The reaction mixture contained $10 \mathrm{mM}$ Tris- $\mathrm{HCl}, \mathrm{pH} 8.3,50 \mathrm{mM} \mathrm{KCl}, 2.5 \mathrm{mM} \mathrm{MgCl}$, $0.1 \%$ Triton X-100,100 $\mu \mathrm{M}$ of each dNTP, $0.75 \mathrm{U}$ of Taq DNA polymerase, and $1 \mu \mathrm{M}$ of each primer. The mixture was cycled 40 times through the following thermal protocol: $94^{\circ} \mathrm{C}$ for $45 \mathrm{~s}, 60^{\circ} \mathrm{C}$ for $45 \mathrm{~s}$, and $72^{\circ} \mathrm{C}$ for 1 min. Products of the amplification reactions were analyzed on $1.5 \%$ agarose gels.

\section{RESULTS}

The best RAPD amplifications obtained with primers P1 or P2 are shown in Fig. 1. The strongest band. Band $\mathrm{A}$, appeared with the primer $\mathrm{P} 1$ and an annealing temperature of $48^{\circ} \mathrm{C}$. Band specificity was tested by comparing Yersinia ruckeri RAPD profiles with those of other environmental microorganisms under the same amplification conditions. With the oligonucleotide P1, some bacterial species gave no amplification pattern (data not shown), while others showed profiles where fragments equivalent to Band $A$ were absent (Fig. 2).

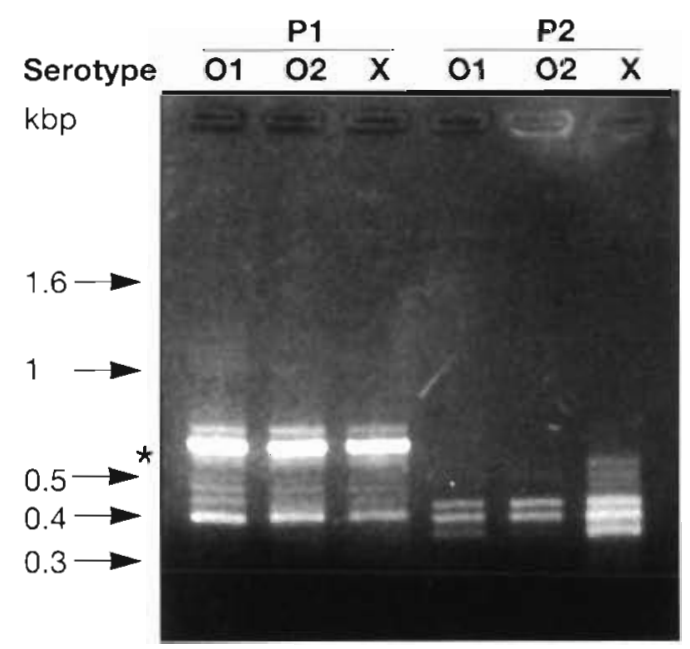

Fig. 1. Results of the RAPD amplifications of Yersinia ruckeri DNA with oligonucleotides P1 or P2. Three serotypes were used: $\mathrm{O} 1, \mathrm{O} 2$, and unknown $(\mathrm{X})$. Arrows and numbers indicate the molecular weights expressed in base pairs (bp). The asterisk indicates the specific band (referred to in the text as Band A) that was cloned and sequenced in order to obtain a Y. ruckeri specific probe 


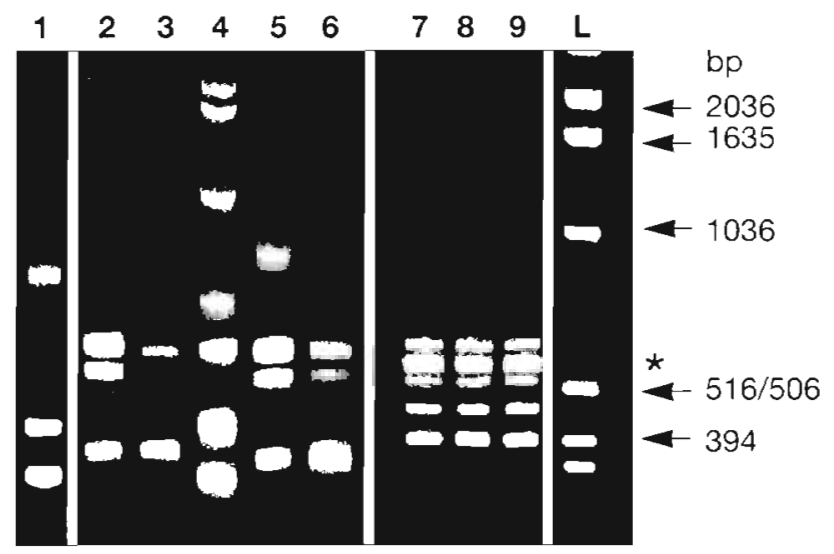

Fig. 2. Band patterns obtained after RAPD amplifications with the nligonucleotide P1 on strains of: Acromonas sulmonicido (1), Vibrio anguillarum $(2,3,4,5,6)$, Yersinia ruckeri (serotypes O1, O2, and unknown $)(7,8,9) . \mathrm{L}=$ standard markers. Asterisk $=$ Band $\mathrm{A}$

The sequence of Band $A$ revealed the presence of $\mathrm{P} 1$ at both ends of a 555 bp fragment (Fig. 3). The nucleotide sequence and the peptide resulting from open reading frame analysis revealed no homology with sequences present in the European Molecular Biology Laboratory (EMBL) data bank. In Southern blot analysis, Band $A$ was found to hybridize with only 1 band of Yersinia ruckeri DNA, while all other bacterial species tested were negative (Fig. 4).

Because Band A appeared to be a good candidate for the specific detection of Yersinia ruckeri, we synthesized 2 specific oligonucleotides, YER1 and YER2, to amplify an internal fragment of it, Band A'. Different $\mathrm{Mg}^{2+}$ concentrations and annealing temperatures were tested in order to optimize the amplification of Band A' from $Y$. ruckeri DNA. The DNA from laboratory strains of serotypes $\mathrm{O} 1, \mathrm{O} 2$, and $\mathrm{X}$ was either extracted or simply released into the test tube by heating the bacteria. The results of PCR amplifications are shown in Fig. 5. The best $\mathrm{Mg}^{2+}$ concentration was $2.5 \mathrm{mM}$ when an annealing temperature of $60^{\circ} \mathrm{C}$ was used. The main band obtained proved to be that of the expected molecular weight. Surprisingly, PCR with whole bacteria was as reliable as PCR with phenol-chloroformextracted DNA, indicating a good availability of genomic DNA upon boiling of bacteria.

In order to avoid cross-recognition problems in PCRbased diagnosis of Yersinia ruckeri, the specificity of the primers was tested. Whole bacteria submitted to PCR gave amplification of Band A' only when Y. ruckeri was used as a template (Fig. 6). In a different set of experiments, Renibacterium salmoninarum was also used as template and found to be negative (data not shown).

To detect Yersinia ruckeri in infected fish, various organs were examined as well as different procedures to release DNA fínin biood and lissues. In artińiciai infections, where fish were injected with live Y. ruckeri, the best results were obtained with DNA released from kidney tissue by treatment with proteinase K. Amplifications from liver, spleen, and blood were less effective (data not shown).

When we amplified DNA released from blood and kidney of farmed trout previously identified as being infected, Yersinia ruckeri was readily detected in the kidney (Fig. 7).

\section{DISCUSSION}

The diagnostic procedure described in the present work exploited the amplification power, molecular specificity, and speed of the PCR technique to provide a sensitive, reliable, rapid, and economical detection system for Yersinia ruckeri in infected trout. It represents a convenient alternative to the conventional bacteriological diagnostic methods. Our approach combined sequentially 2 variants of the PCR: the PCR with a random primer at low stringency or RAPD, and the PCR with specific primers at high stringency. This

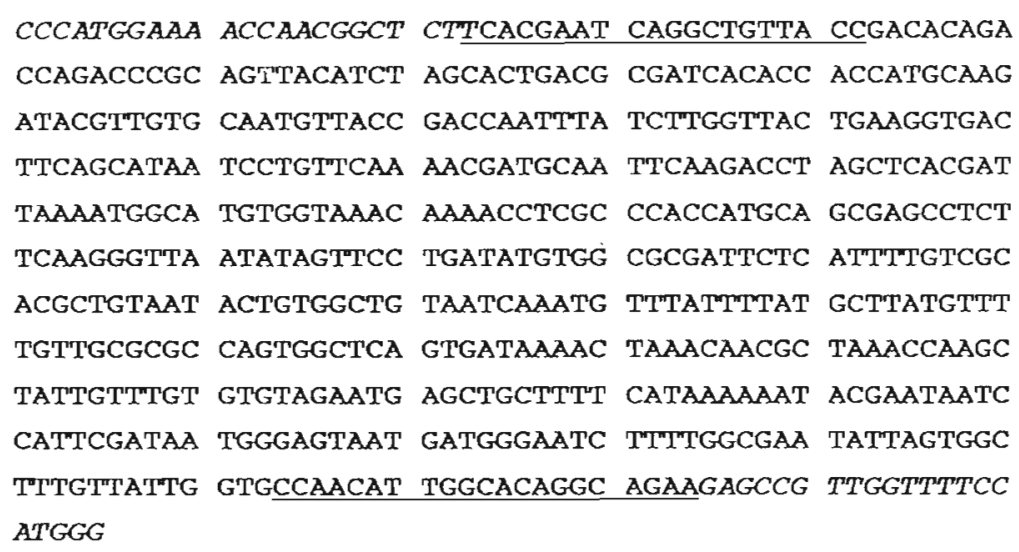

Fig. 3. Nucleotide sequence of the Band A cloned from the RAPD products of Yersinia ruckeri DNA (see Figs. 1 \& 2). The sense and antisense sequences corresponding to the oligonucleotide $\mathrm{P} 1$ are in italics. The 2 sequences corresponding to the specific oligonucleotides YER1 and YER2 are underlined 


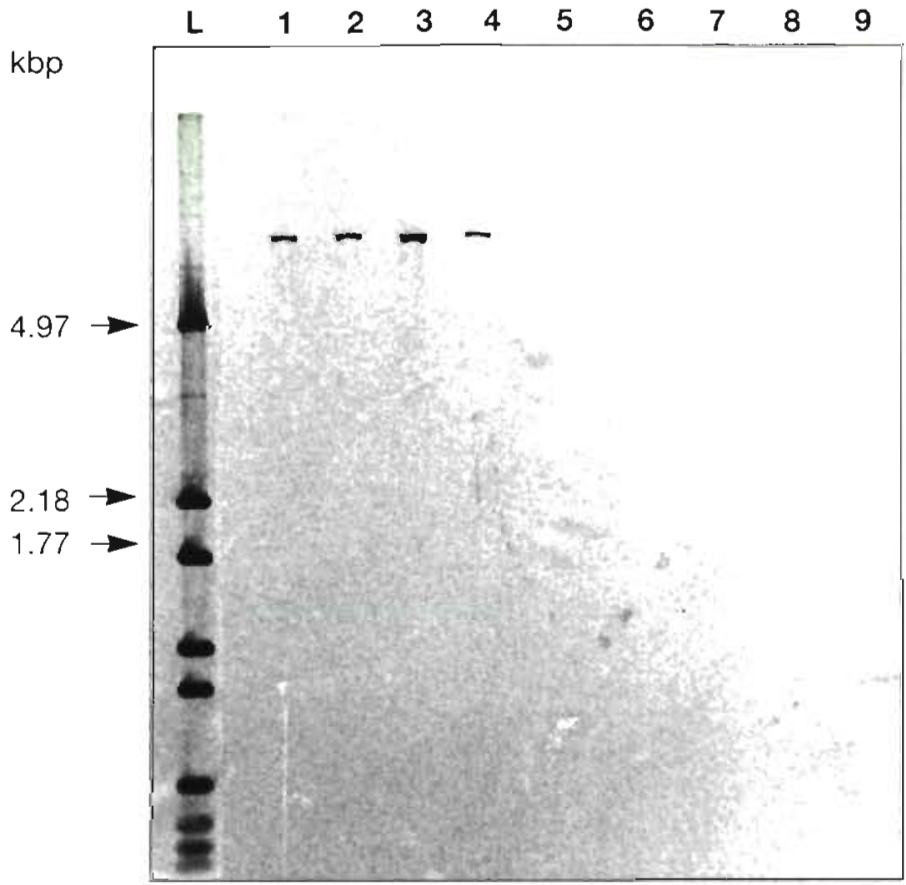

Fig. 4. Southern blot analysis: DNA from different bacterial species and strains was digested with the restriction enzyme Ncol and the resulting fragments were separated by agarose gel electrophoresis and transferred onto a nitro-cellulose membrane. The membrane was hybridized with the digoxigenin-labelled Band A. Lane description: $1=$ Yersinia ruckeri, serotype $01 ; 2=Y$ ruckeri, serotype O2; $3=Y$ ruckeri, serotype unknown; $4=Y$. ruckeri, serotype O1 (Italian strain); $5=$ Aeromonas salmonicida $; 6=$ A. hydrophila $7=$ Vibrio anguillarum

$8=$ Proteus vulgaris $9=$ Escherichia coli $\mathrm{L}=$ standard markers

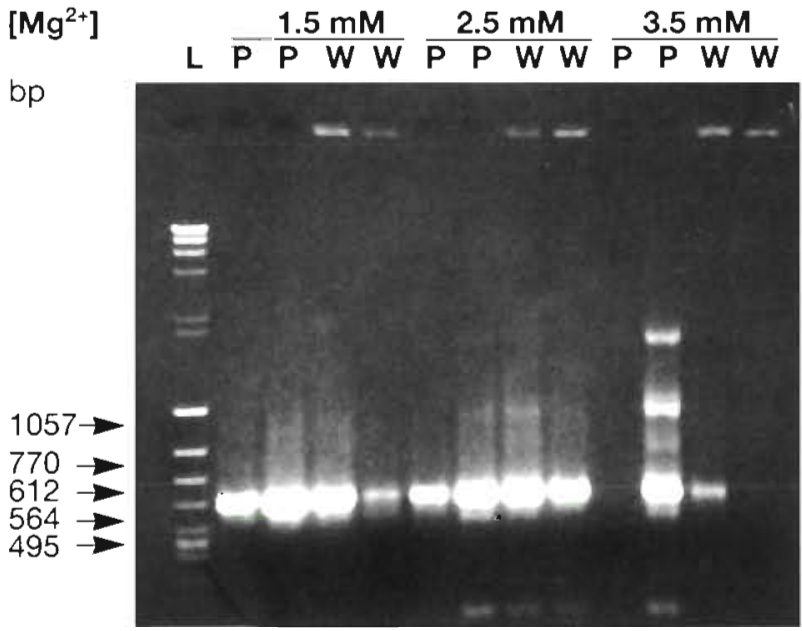

Fig. 5. Results of the PCR amplification of Yersinia ruckeri DNA with the oligonucleotides YER1 and YER2. Three $\mathrm{MgCl}_{2}$ concentrations were tested. As a template, either phenolchloroform purified DNA (indicated as P) or $1 \mu$ l of overnight culture $(W)$ was used. $L=$ standard markers strategy, which has been successfully used in soil microbiology (Hadrys et al. 1992, Fani et al. 1993), is proposed for the first time for use in bacterial ichthyopathology. Its application was straightforward for $Y$ ruckeri and appears promising also for other bacterial fish pathogens.

The use of 23-24-mer random primers resulted in better and more reproducible amplification patterns than those obtained with 10 mers (data not shown), as suggested also by other authors in analogous experiments (Fani et al. 1993). Because the annealing temperature is a crucial parameter, we have checked it in the range 45 to $55^{\circ} \mathrm{C}$ and found that, at $48^{\circ} \mathrm{C}$, only Vibrio anguillarum and Aeromonas salmonicida, among the tested heterologous bacteria, were able to give distinctive amplification products with primer P1. With the homologous Yersinia ruckeri, its 3 tested serotypes (O1, O2, and $X$ ) yielded an identical banding.

Band $\mathrm{A}$ appeared as a prominent and exclusive component of this banding, as indicated by its failure to hybridize with other bacterial DNAs. Its marker quality, size, lack of homology with known sequences, and its deduced genomic origin (both serotypes $\mathrm{O} 1$ and $\mathrm{O} 2$ show Band $A$ while differing markedly in plasmid context) indicated that it could be a convenient source of specific primers
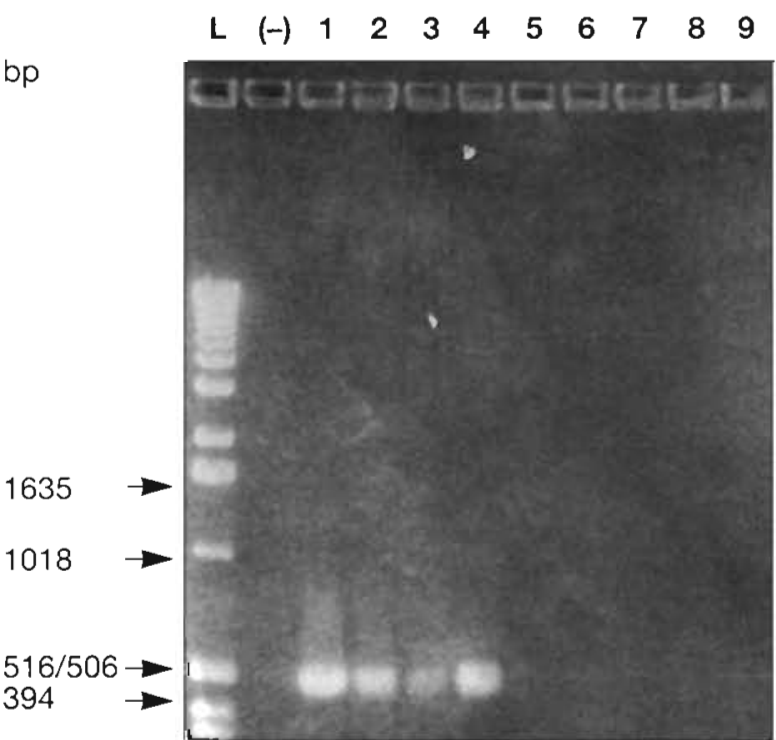

Fig. 6. Results of the PCR amplifications with the oligonucleotides YER1 and YER2. Whole bacteria were used as templates. $1=$ Yersinia ruckeri, serotype $01 ; 2=Y$. ruckeri, serotype O2; $3=Y$. ruckeri, serotype unknown; $4=Y$. ruckeri, serotype $O 1$ (Italian strain); $5=$ Aeromonas salmonicida; $6=$ Aeromonas hydrophila; $7=$ Vibrio anguillarum; $8=$ Proteus vulgaris; $9=$ Escherichia coli. L: standard markers 


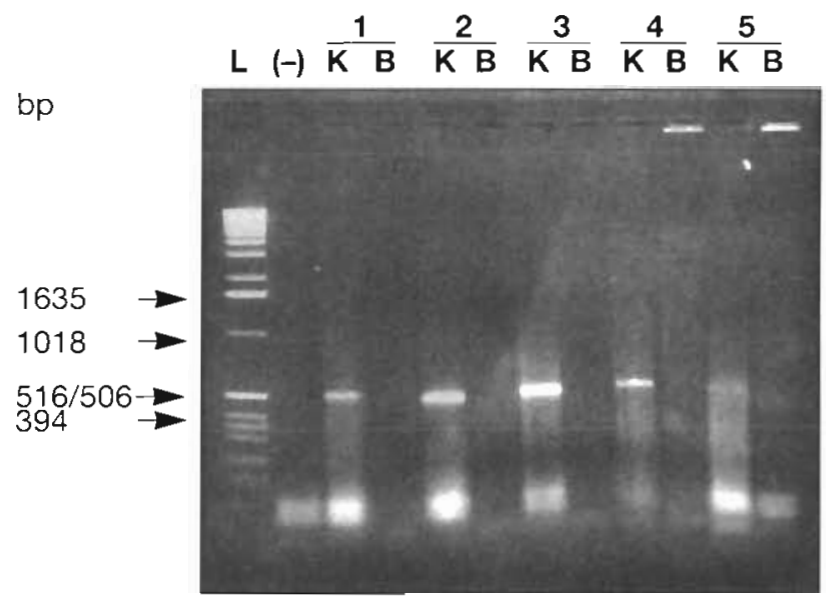

Fiq. 7. PCR screening for Yersinia ruckeri in kidney tissue $(\mathrm{K})$ and blood (B) of 5 infected rainbow trout from fish farms. (-) Negative control. $\mathrm{L}=$ standard markers

As expected, primers YER1 and YER2, designed to amplify Band $A^{\prime}$ which is located between the terminal P1 sequences of Band A, provided a diagnostic PCR assay specific for Yersinia ruckeri, though not discriminating between serotypes $\mathrm{O} 1, \mathrm{O} 2$, and $\mathrm{X}$. Although the risk of cross-amplification of template DNA from other bacteria seems unlikely, other piscine and environmental bacteria need to be tested before the specificity of the assay can be firmly established.

The risk of false positives due to inter-sample contamination must always be taken into account when dealing with easily amplifiable fragments, such as Band A'. Special attention was therefore paid to reducing the number of steps in template preparation from tissues in order to minimize carry-over contamination and to facilitate large-scale screening of infection. The protocol based on proteinase $\mathrm{K}$ digestion prior to amplification is easy to perform and labour-saving. A technician may carry out 96 PCR analyses a day using a 96-well PCR machine and with some practice in tissue collection and processing.

At the moment, kidney tissue has proved to be the best source of pathogen for PCR analysis. Liver, spleen, and blood have proved less satisfactory for PCR analysis. In fact, although a generalized bacteraemia occurs in advanced ERM states, we have failed so far to detect Yersinia ruckeri in blood samples. To explain this failure 2 hypotheses can be advanced: (1) adequate concentrations of the pathogen occur only in kidney tissue; or (2) there is interference by factors in tissues other than the kidney with our DNA release or amplification procedures. The latter supposition could be investigated by mixing tissues before DNA extraction or mixing extracts just before the amplification procedure. Blood testing would be preferable to analyses based on kidney, liver, or spleen because it does not require the death of the sampled fish and is suitable for frequent in situ fish health monitoring on fish farms. Work in progress indicates that PCR diagnosis of $Y$. ruckeri in blood samples might be accomplishable in the near future.

Acknowledgements. Research aided by grant no. AIR1-CT920308 from the European Economic Community. We are indebted to Dr Mauro Zordan for the linguistic revision of the manuscript.

\section{LITERATURE CITED}

Austin B, Austin DE (1987) Bacterial fish pathogens: diseases in farmed and wild fish. Ellis Horwood Ltd Publishing, Chichester, UK

Aznar R, Ludwiq W, Schleifer KH (1993) Ribotyping and randomly amplified polymorphic DNA analysis of Vibrio vulnificus biotypes. Syst appl Microbiol 16:303-309

Bragg RR (1991) Health status of salmonids in river systems in Natal (South Africa). III. Isolation and identification of bacteria. Onderstepoort J Vet Res 58:67-70

Brown LL, Iwama GK, Evelyn TPT, Nelson WS, Levine RP (1994) Use of the polymerase chain reaction (PCR) to detect DNA from Renibacterium salmoninarum within individual salmonid eggs. Dis aquat Org 18:165-171

Fani R, Damiani G, Di Serio C, Gallori E, Grifoni A, Bazzicalupo M (1993) Use of random amplified polymorphic DNA (RAPD) for generating specific DNA probes for microorganisms. Molec Ecol 2:243-250

Davies RL (1991a) Virulence and serum-resistance in different clonal groups and serotypes of Yersinia ruckeri. Vet Microbiol 29:289-298

Davies RL (1991b) Clonal analysis of Yersinia ruckeri based on biotypes, serotypes and outer membrane protein-types. J Fish Dis 14:221-228

Gustafson CE, Thomas CJ, Trust TJ (1992) Detection of Aeromonas salmonicida from fish by using polymerase chain reaction amplification of the virulence surface array protein gene. Appl environ Microbiol 58:3816-3825

Hadrys H, Balick M, Scierwater B (1992) Application of random amplified polymorphic DNA (RAPD) in molecular ecology. Molec Ecol 1:55-63

Ibrahim A, Goebel BM, Liesack W, Griffiths M, Stackebrandt E (1993) The phylogeny of the genus Yersinia based on 16Sr DNA sequences. Microbiol Lett 114:173-178

Kellner-Cousin K, Le Gall G, Despres B, Kaghad M, Legoux P. Shire D, Mialhe E (1993) Genomic DNA cloning of rickettsia-like organisms (RLO) of Saint-Jacques scallop Pecten maximus: evaluation of prokaryote diagnosis by hybridization with a non-isotopically labelled probe and by polymerase chain reaction. Dis aquat Org 15:145-152

Lawrence LM, Harvey J, Gilmour A (1993) Development of a random amplification of polymorphic DNA typing method for Listeria monocytogenes. Appl environ Microbiol 59. $3117-3119$

Mazurier SI, Wernars K (1992) Typing of Listeria strains by random amplification of polymorphic DNA. Res Microbiol 143:499-505

Post G (1987) Textbook of fish health. TFH Publication, Inc, Neptune City, NJ

Quin PJ, Carter ME, Markey BK, Carter GR (1994) Clinical veterinary microbiology. Wolfe Publishing, London

Romalde JL, Iteman I, Carniel E (1991) Use of pulse field electrophoresis to size the chromosome of the bacterial 
fish pathogen Yersinia ruckeri. Microbiol Lett 84:217-226 Romalde JL, Magarinos B, Barja JL, Toranzo AE (1993) Antigenic and molecular characterization of Yersinia rucken: proposal for a new intraspecies classification. Syst appl Microbiol 16:411-419

Sambrook J, Fritsh EF, Maniatis T (1989) Molecular cloning a laboratory manual. Cold Spring Harbor Laboratory Press, Cold Spring Harbor, NY

Sawadogo M, Van Dyke MW (1991) A rapid method for the purification of deprotected oligonucleotides. Nucleic Acids Res 19:674

Responsible Subject Editor: T Evelyn, Nanaimo,

British Columbia, Canada
Scieux C, Grimont F, Regnault B, Bianchi A, Kowalski S, Grimont PAD (1993) Molecular typing of Chlamidia trachomatis by random amplification of polymorphic DNA. Res Microbiol 144:395-404

Welsh J, McClelland M (1990) Fingerprunting genomes using PCR with arbitrary primers. Nucleic Acids Res 18 $7213-7218$

Williams JGK, Kubelik AR, Livak KJ, Rafalski JA, Tingey SV (1990) DNA polymorphisms amplified by arbitrary primers are useful as genetic markers. Nucleic Acids Res 18 $6351-6357$

Manuscript first received: February 16, 1995

Revised version accepted: July 28, 1995 